\title{
High Affinity Copper Uptake Protein 1
}

National Cancer Institute

\section{Source}

National Cancer Institute. High Affinity Copper Uptake Protein 1. NCI Thesaurus. Code C127860.

High affinity copper uptake protein 1 (190 aa, $21 \mathrm{kDa}$ ) is encoded by the human SLC31A1 gene. This protein plays a role in copper ion transport. 